Article

\title{
The Undercurrents of Estonian Broadcasting Regulation, 1992-2014
}




\section{ABSTRACT}

This article explores the ways in which different external and internal factors (especially politics and economics) have encouraged or hindered the evolution of Estonian Public Broadcasting. This article argues that the Estonian government's 'idealisation' of market forces that is supported by European Union (EU) media policy and driven by the common market ideology does not take into account the actual abilities of a small country's media companies to provide a wide range of media services, and thereby limits the offerings of high-quality local content. The research methodology is based on an analysis of EU media policy documents, Estonian media legislation and broadcasters' annual reports in the period from 1992 to 2014. The main finding of this article is that official Estonian media policy is largely shaped by the financial results of private media companies.

INTRODUCTION:

THE ESTABLISHMENT OF

THE EUROPEAN UNION

BROADCASTING REGULATION

An assessment of the impact of globalisation on national policymaking from a theoretical perspective should combine cultural policy studies with globalisation theory. The cultural policy studies perspective remains resolutely national, and policy studies focus on the nation state as the primary locus of decision-making (Flew 2007: 50). Petros losifidis (2013) argues that cultural policy theories view media and communication from a national perspective and largely neglect the global element. Susan Manning (1999: 138) described three different aspects of globalisation: economic, political and cultural. The first refers to the expansion of international trade and investment and the second to the transnational regula- tory systems as well as the spread of liberal political ideology and its institutional forms. Cultural globalisation refers mainly to the spread of Western ideas and cultural practices although various counter flows have also been detected in the recent years (see Tunstall 2008, Rohn 2010). Yet, according to losifidis, globalisation processes, including market-liberalism and free trade policies, have created a situation where

the regulatory agencies' shift away from public interest measures and normative principles towards more rigorous, yet narrow, economics-based assessments of market power is another reason for the emergence of competition policy as a preferred mechanism to tackle issues in media and communications at 
the expense of sector-specific structural and content regulation. (losifidis 2013: 239)

This conclusion coincides with the findings of Jan van Cuilenburg and Denis McQuail (2003), who argue that the nature of public interest has changed and that the new communication policy aiming to serve the public interest is biased towards economic values. This change in media policy has put extra pressure on public service broadcasters (PSB), who used to have an almost undisputed position in Western European media systems. Presently, the forces of economic rationality and globalisation have undermined the original national culture of public service broadcasters (Lowe, Martin 2014: 21). In Western European countries, the PSBs have accumulated strong cultural capital and high legitimation in society, which helps them withstand the pressure of globalisation. However, in Eastern Europe the emerging PSBs did not have the time for capital accumulation, and their legitimation is generally lower (Jakubowicz 2003).

The purpose of this article is to analyse the interdependent changes in Estonian broadcasting legislation, the broadcasting market conditions and European media policy between 1992 and 2014. The analysis concentrates on three main areas and the connections between them:
a) The formation and impact of European Union broadcasting regulations;
b) The formation of Estonian broadcasting regulations;
c) The development of the Estonian television market and private television stations' profitability.

The research methodology is based on an analysis of Estonian broadcasting legislation and the identification of the main causes of the initiation.

To better understand the European Union media (including broadcasting) policy that influences Estonia, we must examine the historical development of this policy.
A simplified approach towards European media policy can be described from two viewpoints. On the one hand, there is the role of EU media policy as a secure media system promoting pluralism, democracy, social cohesion and the freedom of expression. On the other hand, there are the commercial interests of private stakeholders and common market regulation that must be guaranteed. It is a question of ensuring a balanced coexistence of public service broadcasting and commercial media.

There are several European-level activities and policy documents supporting public service broadcasting. The Amsterdam Protocol (European Commission 1997) on the system of public broadcasting in the Member States states 'that the system of public broadcasting in the Member States is directly related to the democratic, social and cultural needs of each society and to the need to preserve media pluralism', but it was left 'to the competence of the Member States to provide for the funding of public service broadcasting insofar as such funding is granted to broadcasting organisations for the fulfilment of the public service remit as conferred, defined and organised by each Member State'. The Parliamentary Assembly's report entitled The Funding of Public Service Broadcasting is also worth mentioning. Although not binding, it does

\footnotetext{
$1 \quad$ Other relevant texts include: Resolution on the future of public service broadcasting from the 4th European Ministerial Conference on Mass Media Policy (Prague, 1994), the Council of Europe's Parliamentary Assembly Resolution 1636 (2008) on indicators for media in a democracy, the Council of Europe's Recommendation 1855 (2009) on the regulation of audiovisual media services, the Council of Europe Committee of Ministers' Recommendations No. R (96) 10 on the guarantee of the independence of public service broadcasting, CM/Rec(2007)3 on the remit of public service media in the information society, $\mathrm{CM} / \operatorname{Rec}(2007) 3$ on the remit of public service media in the information society, $\mathrm{CM} / \operatorname{Rec}(2007) 16$ on measures to promote the public service value of the Internet, $\mathrm{CM} / \operatorname{Rec}(2011) 7$ on a new notion of media, CM/Rec(2012) 1 on public service media governance, CM/Rec(2013)1 on gender equality and media; the Council of Europe's declarations of the Committee of Ministers on the guarantee of the independence of public service broadcasting in the Member States of 27 September 2006 and on the allocation and management of the digital dividend and the public interest of 20 February 2008; UNESCO Convention on the Protection and Promotion of the Diversity of Cultural Expressions of 2005, and the European Commission's (EC) White Paper on a European Communication Policy COM (2006) and Communication from the Commission on the application of State aid rules to public service broadcasting 2009/C 257/01.
} 
summarise clear guidelines for national media policy makers:

National parliaments and ministers responsible for media policy should adapt the funding of public service broadcasting in their countries to the new audiovisual media environment, while safeguarding the public service mission and structure of their broadcasters and allowing them to make full use of the technological opportunities for the benefit of the public at large. (Council of Europe 2009)

The European Parliament resolution on 'Public Service Broadcasting in the Digital Era: The Future of the Dual System' was adopted in November 2010. The resolution underlines

the fundamental role of a genuinely balanced European dual system in promoting democracy, social cohesion and integration and freedom of expression, with an emphasis on preserving and promoting media pluralism, media literacy, cultural and linguistic diversity and compliance with European standards relating to press freedom. (European Parliament 2010)

In the context of this article, there are two points in the resolution that are relevant to PSB funding issues. First, the resolution calls upon Member States to ensure 'sufficient resources to enable public service broadcasters to take advantage of the new digital technologies and to secure the benefits of modern audiovisual services for the general public'. Second, it attempts to balance the European Commission's state aid policy and concerns over the funding of PSBs. The European Parliament "calls further on Member States adequately to address the issue of the underfunding of public service broadcasters' (European
Parliament 2010). In 2012, in the Declaration of the Committee of Ministers on Public Service Media Governance, the Committee of Ministers 'reiterates the Member States' commitment to firmly support the remit, funding, editorial and organisational independence of public service media operating on any relevant platform, and underlines the importance of this support which has not always been uniformly thorough and sufficiently timely' (Council of Europe 2012).

Despite of all these bold declarations and recommendations, the practical results, as will be argued later in this article, are not fully meeting these ideals. The roots of this process can be found in the analysis of European communication policy conducted by Van Cuilenburg and McQuail (2003). Van Cuilenburg and McQuail (2003) argue that the main goal of the Treaty establishing the European Economic Community, signed in Rome in 1957, was the creation of a free (trade) market and the guarantee of capital movement. In the 1950s, when merchandising and industrial manufacturing were making legal international cooperation more efficient and creating nationwide regulations, the public institutions were nationally insured by their monopolistic positions in the markets. The monopolistic position of public broadcasting remained the same in Europe until the end of the 1970s. Since the 1980s, the European common market and the free movement of capital and merchandise have prevailed over the cultural policy that has been left to the competency of the Member States. The first big step in the overall regulation of EU television broadcasting was the enactment of the European Union Television without Frontiers (TWF) Directive in 1989 (89/552/EEC, 1989). The purpose of the document was to create a broadcasting regulation that would serve the interests of the public, including protecting the viewers and the European market through certain limitations.

In 1992, a new chapter titled 'Culture' was added to the Maastricht Treaty, the EU base document. For the first time, crossEuropean cultural activities and goals were 
fixed in a document that overrides the laws of the Member States. According to Jo Bardoel, Leen d'Haenens and Peeters Allerd (2004), the 'Culture' chapter of the Maastricht Treaty was the first clear sign of the tension between the principles of free market competition and the cultural principles supporting pluralism. From the 1990 s onward, larger media corporations started to move into international markets and override the old regulations that limited their activities. Until that time, although they had become cross-national in nature, these large corporations continued to function mainly under state regulations and media-related legislation had to be harmonised across countries.

At the same time, convergence started to assume an important role. The telecommunications policy and the media policy, which used to be executed separately, began to merge into a new, integrated communications policy. According to Van Cuilenburg and McQuail (2003), the purpose of the new communications policy is continuing public interest. However, the nature of public interest has changed. Economic wellbeing has become as important as political well-being, and communication values have become an important part of a society's well-being. Several researchers agree that economic welfare is a dominant value in communications policy (Donders et al. 2014; losifidis 2013; Croteau et al. 2012; McQuail 2010; Harcourt 2005; Picard 2002; Croteau, Hoynes 2001; Murdock, Golding 1989).

One of the goals of the EU regulation is to increase the competitive strength of the European Union, which is lagging behind the economic success of the United States. According to the European Commission's analysis, the European audiovisual industry sustains a trade deficit of $€ 6$ to $€ 7$ billion annually in regard to the American industry (European Commission Action 82). The desire to enhance the European audiovisual industry and protect European culture against American mass culture is understandable, but this involves several dangers and contradictions. In practice, the need to strengthen the competitiveness of the pan-European media industry in the 'digital single market' could end up favouring the development of large international pan-European media conglomerates (Ibrus 2015a). Indeed, eventually it may again be the international American VOD brands (Netflix, Amazon, Google Play, etc.) that dominate the European market (Cunningham, Silver 2013). Further, as a result of growing competition and commercialisation in all the European countries, the effects of commercial broadcasting interests are also continuously increasing in EU media policy. An example of the dominance of market forces was the process of revising the Television without Frontiers (TWF) directive. In the revised and renamed Audiovisual Media Services Directive (AVMSD) (Directive 2007/65/EC, 2007), the object of the regulation was extended from television to audiovisual services in general while the terms for commercial broadcasting were eased.

\section{A BRIEF HISTORY OF THE FORMATION OF THE MODERN ESTONIAN MEDIA LANDSCAPE}

Since the end of the 1980s, the Central and Eastern European (CEE) countries have had the noble aim of changing from communist regimes into free democratic welfare states. Among the important aspects of that development were changes in the media systems. In the transition states, commercial broadcasters were founded, most state-owned print media was privatised, and the state radio and television companies became public service broadcasters. 'Europeanisation', as defined by Karol Jakubowicz (2009), took place. The overall aims of the pan-European media policy are preserving cultural diversity and safeguarding media pluralism. To do so, there are two main approaches to organising the media: a liberal free market strategy and a collectivist-statist strategy (Curran 1997: 139). Having recently been ruled by a communist regime, the collective provision was difficult to introduce in the CEE countries. Therefore, the first strategy was introduced in most of these countries, including the Baltic states. 
Until the beginning of the 1990s, the main TV channels that broadcast on the territory of Estonia were Estonian Television (ETV) and three channels from Russia. The re-transmission of all Russian television and radio channels was terminated in 1993-1994. Since the legal framework had yet to be instituted, the frequencies and networks they had occupied were licensed with temporary licences to newly established private Estonian broadcasters. The former State Radio and Television Committee was reorganised into two independent public service institutions: Estonian Radio and Estonian Television, which also received temporary licences from the Ministry of Culture.

During the initial licensing of the new private broadcasting companies in the early 1990s, media policy makers were particularly concerned about the protection of emerging markets from foreign capital, the enrichment of Estonian culture and the development of the media space. In the context of this article, we can highlight two important general criteria of the issued licences. Firstly, the broadcasting organisation required Estonian capital to have at least $50 \%$ of the votes in the broadcasting company; secondly, at least $35 \%$ of the daily programming output had to originate in Estonia.

It took two years for the Broadcasting Act, which established comprehensive media legislation, to be drafted. The Broadcasting Act (Riigikogu 1994), drawn up with the help of experts from the Council of Europe and European Broadcasting Union, reflected the expectations of the politicians and Estonian broadcasting experts in the 1990s. The main European policy papers that strongly influenced the drafting of the Broadcasting Act included the European Convention on Transfrontier Television (European Commission 1989) and the TWF Directive. The primary objective of the Broadcasting Act, passed by parliament in 1994, was to establish a dual media system: the co-existence of the PSB and the commercial sector. Licenses for private broadcasters were issued through public tenders. The economic conflict that the small size of the broadcasting market would cause was not understood when the law was drafted and passed. The enactmemt of the new legislation was a big step forward in the establishment of the broadcasting landscape in the Republic of Estonia. The law was supposed to create a new broadcasting order suitable for a young democratic state and to secure the freedom of speech and development of a free market economy. After the Broadcasting Act was passed in the summer of 1994, all previously issued temporary licences became invalid, and 32 new five-year broadcast licences were issued under intensely competitive conditions. Estonian Radio and Estonian Television did not need to apply for broadcasting licences since they were now functioning according to the rules established by the Broadcasting Act.

1995 saw the continuing expansion of private broadcasters. Nineteen new radio licences and one TV licence were issued. 1996-1998 saw a decrease in the number of broadcasting licences issued due to the shortage of free frequencies. A total of 13 licences were issued in those three years. In 1999-2002, most of the valid five-year broadcast licences were renewed. No new terrestrial TV channels were granted. In radio, there were 24 newcomers, most of which either replaced discontinued programmes or resulted from changes in or consolidations of ownership. Local studios were shut down and, instead of original local programming, centrally produced programmes were aired over the networks. The roots of this process could be found in affordability; in smaller regions, there was insufficient advertising money or human resources to produce and air many local programmes. During 2004-2008, there were only a few new TV licences issued. All of them were local licences. As of 1 June 2015 , there were 12 valid TV and 29 valid radio licences in Estonia (Technical Regulatory Authority 2015).

The next section analyses the 1994 Act and the amendments made during the intervening years from the following aspects: 
a) The requirements set for the broadcasting licence owners;

b) The advertisement regulation (time, conditions);

c) The TV stations' responsibilities.

At the European level the broadcasting regulation deals with television, and not with radio, and therefore, the following analysis focuses mainly on televisionrelated aspects.

\section{The requirements set for the broadcasting licence owners}

There are two objectives of the legislation that were clearly indicated in the text of the 1994 Broadcasting Act. Firstly, the desire to protect the broadcasting landscape from foreign capital was paramount. This limitation was directly in conflict with the free market principles of the European Community. The second goal was to avoid media concentration.

Despite the legislators' intention to favour local capital, the executive powers preferred to issue broadcasting licences to the representatives of foreign capital. One of the three main emerging commercial broadcasters was AS Eesti Video, with $50 \%$ of its stock owned by Andres Küng, an Estonian citizen residing in Stockholm, who received a broadcasting licence for the television channel EVTV. The second new private broadcaster AS Taska, whose sole owner IImar Taska resided in the US at that time, received a broadcasting licence for the television channel Kanal2. Although, according to the law, local entrepreneurs should have received preference, in reality, the executive power feared the nomenklatura (ex-communists). The third national player was the commercial broadcaster AS Reklaamitelevisioon, with $90 \%$ of the stock owned by Estonian companies, but the key person was the former director of Estonian Television, who received a licence for broadcasting only on weekend mornings (Jõesaar 2005).

Since the country wished to accede to the European Union, the legislation related to Estonian audiovisual policy had to be consistent with EU norms. One of the EU requirements was the elimination of any limitations on the broadcasting stations' proprietary relationships. In 2000, the Parliament of Estonia adopted the Amendment to the Broadcasting Act, which brought the latter into conformity with EU requirements (mainly the ones arising from the Television without Frontiers Directive). The Estoniacentric limitation related to broadcasting licence ownership was revoked. From the aspect of the free movement of capital, it was a case of liberalising a protectionist market.

\section{The advertisement regulation and its amendment}

The 1994 Broadcasting Act defines advertisement, sets the criteria for advertisements, determines the amount and location of advertisement that is allowed in a programme and lists forbidden or conditional advertisements (Riigikogu 1994).

Commercials must be clearly separated from the programme. The maximum time limit for commercials was set at 12 minutes in any section of the programme and limited to $15 \%$ of the programme's daily broadcast time. The limitation of commercials on private channels is derived from the respective European regulations. The law limited the maximum time dedicated to commercials on Estonian Television to five minutes per hour. This was the first legal step that limited ETV's actions in the commercial market and created favourable development conditions for the private channels.

Programmes could be interrupted for commercial breaks, except in the case of children's programmes and religious services. Commercials were not allowed to directly precede or follow the latter.

From the point of view of the television stations' economic activities, it is important to mention that, in addition to commercials, the law allowed the use of sponsorship, and therefore, also the presentation of short clips naming the sponsors and their brands. Since the definition of sponsorship announcements in the law was vague, the 
commercial television stations regularly broadcast commercials while calling them sponsorship. In practice, this meant that there were two important aspects affecting the economic activities of the television stations. Firstly, since the sponsorship announcements were not included among the 12-minute limitation for commercials, it was possible to override the limitation by using sponsorship announcements. Thus, the law gave commercial broadcasters a legal way to sell more time slots for commercials at peak times of demand. Secondly, it was also possible to advertise the services and products that were forbidden in regular television commercials (such as gambling and alcohol brands) as sponsorships.

The 1994 law did not deal with product placement, subconscious advertisement techniques or direct offers. From the perspective of economic activity, it should be mentioned that the advertisement of alcoholic beverages, tobacco products, firearms and prostitution were completely forbidden.

The advertisement law adopted in 1997 liberalised the rules on alcohol advertisements. The enactment of the advertisement law annulled the prohibition of alcohol advertisements in public broadcasting (Riigikogu 1997a). This change meant additional income for all the television stations. The amendment to the Broadcasting Act in 1999 made many important additions to the paragraphs related to advertisements. In addition to the existing advertisement and sponsorship opportunities, a regulation for direct offers was created, and the conditions for interrupting programmes for commercial breaks were specified (among other things, news broadcasts and children's programmes, which were longer than 30 minutes, could have commercial breaks). The prohibition of subconscious advertisement techniques and product placement was enacted. All the amendments were derived from the Television without Frontiers Directive. The 1999 amendments ordered the conditions for broadcasting television commercials but did not have a major impact on the advertising revenues of the television channels.
The major impact on commercial broadcasters' revenues was caused by the amendment to the Broadcasting Act that was adopted in 2002. This prohibited the broadcasting of commercial and sponsorship announcements on Estonian Television as of 1 June 2002. No other change of equal importance was implemented. The amendment to the law limited the number of nationwide commercial broadcasting licences to two (Riigikogu 2002).

The Estonian audiovisual media legislation was brought into full conformity with the Audiovisual Media Services Directive in 2010. Within the context of this article, the advertisement requirements (a new term was introduced, i.e., audiovisual communication that includes inter alia, television advertising, sponsorship, teleshopping and product placement) had become considerably more liberal in comparison to the previous regulation; the advertisement and programme separation clause was replaced by a rule that advertising must be readily recognisable, and product placement was liberalised (with some restrictions). However, in reality, the European Commission was just legalising all the new advertisement techniques that were already in use. The result directly favoured the advertisers' interests, which in turn undermined the viewers' interests and accelerated general media commercialisation. On the other hand, one must admit that because of general media commercialisation and liberal regulation, the change in the directive was actually an attempt to bring the regulation into conformity with the existing situation.

\section{The 'TV stations' responsibilities}

The first version of the Broadcasting Act from 1994 defines broadcasts and programmes, and several requirements for the programmes and broadcasts were established. According to the provisions of the law and broadcasting licence conditions, a broadcasting station has the right to freely decide the contents of its broadcasts and programmes. A special requirement applied to news programmes. At least 5\% the daily programme time had to consist of 
news programmes, except for Sundays and national holidays. This was the only specific obligation placed on the broadcasters.

The establishment of obligations in this way reflects the liberal media policy of the legislators at the time. The broadcasting licences were also issued liberally: all unoccupied technical frequencies were distributed. It was hoped the market would regulate itself.

Based on the evidence presented so far, one can say that, from the viewpoint of the broadcasting station's economic activity, the minimum requirement for news programmes had the most important effect. It was the only obligation for private channels that was directed towards serving the public interest. The 5\% news requirement for the main free-to-air channels is still in force. However, it should be said that this limitation is starting to become irrelevant, since news programmes are not defined and their contents is not supervised. For example, this situation has allowed the private broadcaster Kanal2 to utilise an infotainment format for their main news broadcast. Greater and more detailed obligations were established for public service broadcasting than for private media.

To bring the legislation of the Republic of Estonia into conformity with the EU before accession to the European Union, major changes took place in 1999 and 2000 (Riigikogu 1999, Riigikogu 2000). The obligations implemented for the broadcasting organisations are consistent with EU requirements, wherein $10 \%$ of broadcasting time must be reserved for independent European producers and the majority of the broadcasting time should be reserved for European programming. It is important to point out that the Estonian legislators set an additional obligation: $50 \%$ of the productions to be broadcast during prime time should be about Estonian current affairs or Estonian cultural heritage. This obligation was deleted from the legislation in 2010 when the Audiovisual Media Service Directive (AVMSD) was implemented.

Despite the law's noble goals, the programme selection offered to viewers did not become more diverse, and private channels did not broadcast any more productions about contemporary Estonia or Estonian cultural heritage (Šein 2005, Gross 2012). Of course, it is another matter if the entertainment shows and drama series produced in Estonia are considered to be reflections of contemporary life and therefore a part of cultural heritage.

\section{MARKET FORCES HELP TO DIMINISH THE IDEALS OF THE BROADCASTING ACT}

The market size determines the available resources for media development (Puppis 2009; Lowe, Nissen 2011). If the market is large enough for business to be profitable, and resources are available, the general media needs (variety, pluralism, etc.) are fulfilled. In smaller countries, there are fewer available resources and there is the risk of market failure (Doyle 2002; Lowe, Nissen 2011; Jõesaar 2011). Due to market limitations, it is unprofitable to launch a wide range of media products in smaller markets. There will be less diversity of content in smaller and less wealthy states than in larger and richer markets (Lowe, Nissen 2011). Estonia with its population of approximately 1.3 million people and a gross domestic product (GDP) of $\$ 25.9$ billion is one of the small countries (The World Bank 2015). The GDP per capita in Estonia is more than 30\% lower than the EU-28 average (Eurostat 2015).

In the early 1990s, television stations were experiencing economic difficulties, and they had to look for additional investors in order to cover their losses. The first major (and still existing) investment was made by the Swedish media concern Modern Times Group AB when they acquired the majority share of the commercial channel EVTV. To comply with the Broadcasting Act valid at that time, the owners of EVTV drafted a contract stating that the Estonians formally controlled the majority of the vote, although they owned a smaller portion of the shares. The same solution was used in 1995-1996 when EVTV and RTV merged to form the new television station TV3. In order to be in 
compliance, the Norwegian media company Schibsted ASA used the same scheme when acquiring shares of Kanal2 in 1995. In the case of Kanal2, there was also the issue of potential media concentration. The owner of Kanal2, Eesti Meedia AS, also owned, and still owns, the largest daily newspaper, several county newspapers and thereafter acquired a chain of radio stations. This was a clear violation of the anti-media concentration article in the Broadcasting Act, but due to the lack of will and the (purported) inadequate wording of the law, the executive power that should have been responsible for supervising the broadcasting licences never tried to deal with the problem (Seireraport 2005).

The other contradiction with European legislation was the 2002 Amendment of the Broadcasting Act, which introduced a licence fee for the commercial broadcasters and limited the number of nationwide broadcasting licences to two. With that move, the market was closed for the newcomers. Both changes - the liberalisation of the proprietary mentioned earlier and the closure of the market - directly served the interest of the international media companies that were already in the market. Now, they officially became the sole owners of the private but monopolised broadcasting stations. The law was brought into conformity with the existing situation. Secondly, with the closure of the market, they ensured an advantageous economic environment for themselves. The results of the changes can be seen in the change of companies' profitability during the years 2002-2007

\section{(Table 1).}

The 'good times' lasted until 2008. From the mid-2000s onward, new media developments and the rapidly increasing numbers of new foreign channels made accessible through cable, satellite TV and emerging IPTV platforms, endangered the Estonian commercial broadcasters' positions. Broadcasters faced audience and revenue losses. The switchover from terrestrial analogue transmission to the digital platform in 2010 further increased the competition. And on top of that, the 2008 economic recession reduced the value of the Estonian market by one third (TNS Emor 2014).

To support the digital switchover and ease the difficult financial situation of the private broadcasters, the Amendment of the Broadcasting Act in 2008 annulled the broadcasting licence fees as of 1 January 2009. The next supportive move for commercial broadcasters was provided by the legislature in 2012 when the Estonian Parliament adopted an amendment to the Electronic Communication Act, which allowed '[b]roadcasters offering free-to-air television services to have the right to ask cable operators to pay a reasonable fee for the retransmission of their television programmes' (Riigikogu 2012). This provided the private broadcasters with the opportunity to earn additional revenue.

Based on the analysis of aforementioned sources, the main indicators of broadcasting regulation and private channel activities are summarised in Table 2.

It should be recognised that, despite the favourable legal environment and oligopoly structure of the market between 2001 and 2007, the unfavourable circumstances in recent years resulted in considerable financial losses for the private broadcasters. As a result, during their entire existence, the two main Estonian commercial broadcasters have cumulatively suffered losses. On the programme side, commercialisation is still the trend, but during the last period, acquisition-driven entertainment has been replaced by local entertainment content (Rohn 2014; Treufeldt 2011; Šein 2010, 2005).

\section{CONCLUSIONS}

Because Estonia lacks a long history of public-service culture, its public broadcaster Eesti Rahvusringhääling (ERR) is facing issues similar to many other publicservice broadcasters in CEE countries (Jakubowicz 2007). These include low political legitimation, which is evidenced by a low level of funding (European Broadcasting Union 2014). On the other hand, the trust of the audiences in the PSB in Estonia is as high at 83\% (Eesti Rahvusringhääling 2015), 
4.0

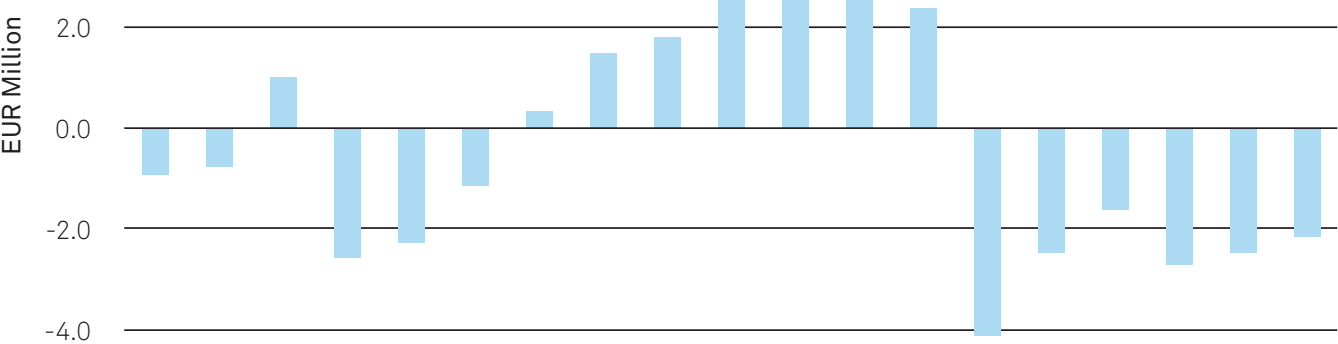

$-6.0$

ஓ গু

Profit/Loss

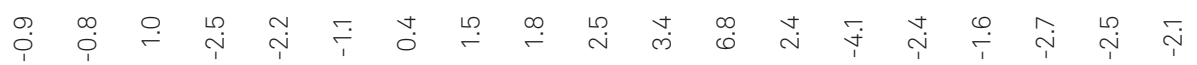

(EUR M)

TABLE 1. Summarised profit and loss of commercial broadcasters Kanal2 and TV3 during 1996-2014. Source: Author's calculations based on companies' annual reports. 


\begin{tabular}{|c|c|c|c|c|}
\hline & 1994-1999 & $2000-2001$ & $2002-2007$ & 2008 and further \\
\hline Content regulation & weak & \multicolumn{2}{|c|}{$\begin{array}{l}\text { strengthened, implementation of TWF } \\
\text { directive and additional local requirements }\end{array}$} & diminishing \\
\hline $\begin{array}{l}\text { Advertisement } \\
\text { regulation }\end{array}$ & weak & $\begin{array}{l}\text { strengthened, } \\
\text { implementation } \\
\text { of TWF directive } \\
\text { requirements }\end{array}$ & $\begin{array}{l}\text { steady de facto } \\
\text { liberalisation }\end{array}$ & $\begin{array}{l}\text { also de jure } \\
\text { liberalisation }\end{array}$ \\
\hline PSB programmes & diverse & entertainment growth & \multicolumn{2}{|l|}{ diverse } \\
\hline $\begin{array}{l}\text { Private channels' } \\
\text { programmes }\end{array}$ & diverse & $\begin{array}{l}\text { variety of genres } \\
\text { offered decreases }\end{array}$ & $\begin{array}{l}\text { tendency towards } \\
\text { acquisition-driven } \\
\text { entertainment }\end{array}$ & $\begin{array}{l}\text { driven by local } \\
\text { entertainment }\end{array}$ \\
\hline Market & open & \multicolumn{2}{|l|}{ protected } & open \\
\hline $\begin{array}{l}\text { Private channels' } \\
\text { economic indicators }\end{array}$ & loss & breakeven & profit & loss \\
\hline
\end{tabular}

TABLE 2. Four phases in Estonian broadcasting sector. 
and the market share is equal to that of the main private broadcasters (TNS Emor 2015). At the same time, the overall broadcasting paradigm is changing. Powered by rapid technological development, convergence, globalisation, commercialisation and social media have challenged all the traditional media models. Traditional PSB remit should meet the demands of an information society. This is a challenge to the funding and governance of public-service media (PSM). At the same time, attempts to expand ERR services into online and mobile environments have met both external critiques from the private sector as well as internal challenges caused partly by budgetary tensions (Ibrus, Merivee 2014). Additional financial resources could help ERR grow from a traditional public service broadcasting company into a public service media company by introducing innovative new services on all platforms (Ibrus, Ojamaa 2014). Indeed, in this new era, and especially in smaller countries, public service media institutions could become innovation drivers for the national media services ecosystems (Ibrus 2015b). Yet, funding increases are a question of political will. And this will is often volatile and therefore changes in media policy that would move it towards a new media paradigm would be both supportive and limiting for public-service media (Doyle 2013; Lowe, Martin 2014).

Analyses of the amendments to Estonian broadcasting legislation over the last two decades show that Estonian broadcasting legislation has adhered to the minimum requirements established by EU directives and has been more supportive of the commercial sector than the PSB. As shown above, at the EU level, there are no binding mechanisms dictating the minimum funding level that a Member State should guarantee for the PSB. There are no European Union financial instruments dedicated to the enhancement of the public service media, as there are, for example, for infrastructure development. Decisions on remit, funding model and funding level of the PSB are left to the Member State. There is no common PSB model or standard that applies to all countries (European Commission 2011). Governance and financing models, remit, legal framework, relations with political powers and accountability obligations towards society vary widely. Overall, EU media policy is subordinated to economic policy, and the public service media is treated similarly to all other media companies (Harcourt 2005, Iosifidis 2013, Jõesaar 2011). The European Commission has been willing to put PSB under market rules (European Commission 2009a, 2009 b).

The market-driven economic and political globalisation and liberal regulatory processes may result in the decreased diversity of private media output. As stated above, one of the roles of the PSB is to balance that trend, to safeguard pluralism and to secure diversity. For that task, a proper regulatory framework should be established, and sufficient funding should be granted for PSBs in all Member States. Without the support of the EU's binding legal instruments, Estonian public service broadcasting lacks the funding required to achieve the same powerful and legitimate position as Western European and Nordic public broadcasters (European Broadcasting Union 2014). Under these circumstances, there should be legal instruments to ensure that PSBs are not underfunded, instead of the European Commission's concerns for the overfunding of PSBs causing possible violations of state aid regulations. In cases of underfunding, it is clear that PSB remits might not be fulfilled because the citizens' rights to receive democratic and pluralistic content are not protected.

The situation can best be described as follows: the political-administrative system in Europe, as well as in Estonia, primarily views the economy (including the media economy) as needing to be liberal and regulated as little as possible; however, regulation is also necessary to guarantee the public sector media (broadcast) activities' needed to fulfil the PSB remit. The basis of this conflict is the limited legitimacy of the PSB in the political-administrative system. The general EU (economic) policy is oriented towards the enlargement of general liber- 
alisation. The European Commission's main policy is to support the common market and secure free competition. At the same time, EU media policy does not consider the different historical, political, cultural and economic backgrounds of the Central and Eastern European countries compared to Western Europe. Furthermore, EU media policy also does not take into account the specific needs of culturally fragile and vulnerable smaller countries that have fewer resources. This article demonstrates how the trends both at the EU level and in national media policy making tend to favour and support the commercial players. The development of this trend could pose a threat to the fragile local cultural environment, which could, in turn, hinder the democratic processes of the society.

\section{REFERENCES}

Bardoel, Jo; d'Haenens, Leen; Allerd, Peeters 2004 Defining Distinctiveness: In Search of Public Broadcasting Performance and Quality Criteria. S.l.: Ripe@2004. http://ripeat.org/2010/defining-distinctiveness-insearch-of-public-broadcasting-performance-andquality-criteria/.

Croteau, David; Hoynes, William 2001. The Business of Media: Corporate Media and the Public Interest. Thousand Oaks: Pine Forge Press.

Croteau, David; Hoynes, William; Milan, Stefania 2012. Media/Society: Industries, Images, and Audiences. Los Angeles: Sage.

Cuilenburg, Jan van; McQuail, Denis 2003. 'Media Policy Paradigm Shifts: Towards a New Communications Policy Paradigm? - European Journal of Communication 18, 2, 181-207.

Cunningham, Stuart; Silver, Jon 2013. Screen

Distribution and the New King Kongs of the Online World. London: Palgrave Pivot.

Curran, James 1997. 'Rethinking the Media as a Public Sphere'. - Peter Golding, Graham Murdock (eds.), The Political Economy of the Media. Vol. 2. Communication and the Common Good. Cheltenham: Edward Elgar, 120-150.

Donders, Karen; Pauwels, Caroline; Loisen, Jan 2014. The Palgrave Handbooks of European Media Policy. Basingstoke, New York: Palgrave Macmillan.

Doyle, Gillian 2002. Media Ownership: The Economics and Politics of Convergence and Concentration in UK and European Media. London: Sage.

Doyle, Gillian 2013. Understanding Media Economics. London: Sage.

Flew, Terry 2007. Understanding Global Media. London: Palgrave Macmillan.

Harcourt, Alison 2005. The European Union and the Regulation of Media Markets. Manchester, New York: Manchester University Press.

Ibrus, Indrek 2015a. 'Mida arvata ühtsusest kultuuriturul'. - Sirp, 5 June. http://www.sirp.ee/s1-artiklid/ c9-sotsiaalia/mida-arvata-uhtsusest-kultuuriturul/ Ibrus, Indrek 2015b. 'The Replacement of Media Policies with (Media) Entrepreneurship Policies: A View from Europe's Periphery.' - International Journal of Digital Television 6, 3, 311-318.

Ibrus, Indrek; Merivee, Astra 2014. 'Strategic Management of Crossmedia Production at Estonian Public Broadcasting. - Baltic Screen Media Review 2, 96-120. http://publications.tlu.ee/index.php/bsmr/article/ view/222.

Ibrus, Indrek; Ojamaa, Maarja 2014. 'What is the Cultural Function and Value of European Transmedia Independents?' - International Journal of Communication 8, 2283-2300.

losifidis, Petros 2013. Global Media and Communication Policy. Basingstoke, New York: Palgrave Macmillan. Jakubowicz, Karol 2003. 'A Square Peg in a Round Hole: The European Union's Policy on Public Service Broadcasting. - Journal of Media Practice 4, 3, 155-176. Jakubowicz, Karol 2007. Rude Awakening: Social and Media Change in Central and Eastern Europe. Cresskill: Hampton Press.

Jakubowicz, Karol 2009. 'The Highways and Byways of "Europeanzation" in the Media'. - Central European Journal of Communication 1, 2, 5-11.

Jõesaar, Andres 2005. Avalik-õigusliku ringhäälingu legitimatsioon. Eesti kogemus rahvusvahelises kontekstis. MA thesis. Tartu Ülikool. Tartu. Jõesaar, Andres 2011. EU Media Policy and Survival of Public Service Broadcasting in Estonia 1994-2010. Dissertationes de mediis et communicationibus Universitatis Tartuensis 14. Tartu:Tartu University Press.

Gross, Heikko 2012. 'Tele- ja raadiokanalite programmianalüüs'. - Indrek Ude, Peeter Vihalemm (eds.), Eesti Akadeemilise Ajakirjanduse Seltsi aastaraamat 
2010/2011. Tartu: Eesti Akadeemiline Ajakirjanduse Selts, 73-80

Lowe, Gregory F.; Nissen, Christian (eds.) 2011.

Small Among Giants: Television Broadcasting in Smaller Countries. Göteborg: Nordicom.

Lowe, Gregory F.; Martin, Fiona 2014. 'The Value and the Values of Public Service Media'. - Gregory F. Lowe, Fiona Martin (eds.), The Value of Public Service Media: RIPE@2013 Reader.Göteborg: Nordicom, 19-40. Manning, Susan 1999. 'Introduction'. - Journal of World-Systems Research 5, 2,137-141.

McQuail, Denis 2010. McQuail's Mass Communication Theory. 6 th ed. New Delhi: Sage.

Murdock, Graham; Golding, Peter 1989. 'Information Poverty and Political Inequality: Citizenship in the Age of Privatized Communications'. - Journal of Communication 39, 3, 180-195.

Picard, Robert G. 2002. The Economics and Financing of Media Companies. New York: Fordham University Press. Puppis, Manuel 2009. 'Media Regulation in Small States'. - International Communication Gazette 71, 7, 7-17.

Rohn, Ulrike 2010. Cultural Barriers to the Success of Foreign Media Content: Western Media in China, India, and Japan. Frankfurt: Peter Lang.

Rohn, Ulrike 2014. 'Small Market, Big Format: Idols in Estonia: - Baltic Screen Media Review 2, 122-137. http://publications.tlu.ee/index.php/bsmr/article/ view/22.

Seireraport 2005. Televisioon Euroopas: regulatsioon, poliitika, sõltumatus. S.l.: Eesti Ringhäälingute Liit. Šein, Hagi 2005. Suur teleraamat. 50 aastat televisiooni Eestis 1955-2005. Tallinn:TEA.

Šein, Hagi 2010. 'Rahvusringhäälingu kuvandimaastik' - Indrek Ude, Peeter Vihalemm (eds.), Eesti Akadeemilise Ajakirjanduse Seltsi aastaraamat 2009/2010.

Tartu: Eesti Akadeemiline Ajakirjanduse Selts, 92-104. Treufeldt, Indrek 2011. 'Telemaailma uued tsüklonid'. Indrek Ude, Peeter Vihalemm (eds.), Eesti Akadeemilise Ajakirjanduse Seltsi aastaraamat 2010/2011. Tartu: Eesti Akadeemiline Ajakirjanduse Selts, 81-90. Tunstall, Jeremy 2008. The Media Were American: U.S. Mass Media in Decline. New York: Oxford University Press.

\section{SOURCES}

Council of Europe 1989. European Convention on Transfrontier Television. http://conventions.coe.int/ Treaty/en/Treaties/html/132.htm.

Council of Europe 1994. Resolution n.1 on the future of PSB adopted at the 4th European Ministerial Conference on Mass Media Policy. Prague.

http://www.coe.int/t/dghl/standardsetting/media/doc/ DH-MM\%282006\%29004_en.pdf.

Council of Europe 1996. Recommendation No. R (96) 10 of the Committee of Ministers to Member States on the Guarantee of Independence of Public Service Broadcasting.

http://www.coe.int/t/dghl/standardsetting/media/Doc/ CM/Rec\%281996\%29010\&ExpMem_en.asp.

Council of Europe 1999. Resolution of the Council and

Representatives of the Governments of the Member States concerning Public Service Broadcasting, Official Journal, C 30/1. http://eur-lex.europa.eu/legal-content/ EN/TXT/?uri=OJ:C:1999:030:TOC

Council of Europe 2007. Recommendation CM/ $\operatorname{Rec}(2007) 3$ of the Committee of Ministers to member states on the remit of public service media in the information society. https://wcd.coe.int/ViewDoc.jsp?id $=1089759$.

Council of Europe 2007. Recommendation CM/ Rec(2007)16 of the Committee of Ministers to member states on measures to promote the public service value of the Internet. https://wcd.coe.int/ViewDoc. jsp?id=1207291.

Council of Europe 2009. Public service media governance: looking to the future. 1st Council of Europe Conference of Ministers responsible for Media and New Communication Services. Background text. Media and Information Society Division. Directorate General of Human Rights and Legal Affairs. Council of Europe. http://www.coe.int/t/dc/files/ministerial_conferences/ 2009_media_communication/default_en.asp.

Council of Europe 2009. Recommendation n. 1878 of the Parliamentary Assembly on the funding of public service broadcasting. 25 June. http://assembly.coe.int/ Documents/AdoptedText/ta09/EREC1878.htm. Council of Europe 2010. DDH-MC(2010)002

Recommendations and resolutions adopted by the Parliamentary Assembly of the Council of Europe in the field of media and new communication services. Media and Information Society Division. Directorate General of Human Rights and Legal Affairs. Council of Europe. Strasbourg.

Council of Europe 2010. DH-MC(2010)001

Recommendations and Declarations of the Committee of Ministers of the Council of Europe in the field of media and new communication services. Media and Information Society Division. Directorate General of Human Rights and Legal Affairs. Council of Europe. Strasbourg.

Council of Europe 2010. DH-MM(2010)001 European Ministerial Conferences on Mass Media Policy \& Council of Europe Conferences of Ministers Responsible for Media and New Communication Services. Texts Adopted. Media and Information Society Division. Directorate General of Human Rights and Legal Affairs. Council of Europe. Strasbourg.

Council of Europe 2011. Recommendation CM/

Rec(2011)7 of the Committee of Ministers to member states on a new notion of media. https://wcd.coe.int/ ViewDoc.jsp?id=1835645.

Council of Europe 2012. Recommendation CM/

Rec(2012) 1 of the Committee of Ministers to member States on public service media governance.

https://wcd.coe.int/ViewDoc.jsp?id=1908265.

Council of Europe 2012. Declaration of the Committee of Ministers on Public Service Media Governance (Adopted by the Committee of Ministers on 15 February 2012 at the 1134th meeting of the Ministers' Deputies). https://wcd.coe.int/ViewDoc.jsp?id=1908241\&Site=CM 
$\&$ BackColorlnternet $=\mathrm{C} 3 \mathrm{C} 3 \mathrm{C} 3 \&$ BackColorlntranet $=\mathrm{EDB}$ 021\&BackColorLogged =F5D383.

Council of Europe 2012. Recommendation CM/ Rec(2012) 1 of the Committee of Ministers to member States on public service media governance (Adopted by the Committee of Ministers on 15 February 2012 at the 1134th meeting of the Ministers' Deputies).

https://wcd.coe.int/ViewDoc.jsp?id=1908265\&Site=CM \&BackColorlnternet $=\mathrm{C} 3 \mathrm{C} 3 \mathrm{C} 3 \&$ BackColorlntranet $=\mathrm{EDB}$ 021\&BackColorLogged =F5D383.

Council of Europe 2013. Recommendation CM/ Rec(2013) 1 of the Committee of Ministers to Member States on gender equality and media.

https://wcd.coe.int/ViewDoc.jsp?id =2087343.

Eesti Rahvusringhääling 2015. Eesti Rahvusringhäälingu arengukava 2016-2019. http://err.ee/files/ ERR-arengukava\%202016-2019.pdf.

European Broadcsting Union 2014. Funding of Public Service Media 2014. http://www3.ebu.ch/contents/ publications/restricted/media-intelligence-service/ funding-of-PSM-2014.html.

European Commission 1989. Council Directive 89/552/ EEC of 3 October 1989 on the coordination of certain provisions laid down by Law, Regulation or Administrative Action in Member States concerning the pursuit of television broadcasting activities. http://eur-lex.europa.eu/LexUriServ/LexUriServ.do? uri=CELEX:31989L0552:EN:HTML.

European Commission 1997. 11997D/PRO/09 Treaty of Amsterdam amending the Treaty on European Union, the Treaties establishing the European Communities and certain related acts - Protocol annexed to the Treaty of the European Community - Protocol on the system of public broadcasting in the Member States. Official Journal C 340, 10/11/1997 P. 0109.

http://eur-lex.europa.eu/LexUriServ/LexUriServ. do?uri=CELEX:11997D/PRO/09:EN:HTML.

European Commission 2001. Communication from the Commission on the application of State aid rules to public service broadcasting. Official Journal C 320, 5-11. http://eur-lex.europa.eu/legal-content/EN/ TXT/?uri=CELEX:52001XC1115(01).

European Commission 2006. White paper on

European Communication Policy. European Commission COM(2006) 35, February.

http://europa.eu/documents/comm/white_papers/pdf/ com2006_35_en.pdf.

European Commission 2009a. New Communication on State Aid to PSB. European Commission, 2 July. http://europa.eu/legislation_summaries/competition/ state_aid/cc0014_en.htm.

European Commission 2009b. Communication from the Commission on the application of State aid rules to public service broadcasting 2009/C 257/01. Official Journal C 257, 27 October. http://eur-lex.europa.eu/ legal-content/EN/TXT/?uri =celex:52009XC1027(01). Europen Commission (n. d.). Action 82: Implement the Audiovisual Media Services Directive on cultural diversity. Digital Agenda For Europe. A Europe 202202 Initiative. European Commission.

http://ec.europa.eu/digital-agenda/en/pillar-vii-ictenabled-benefits-eu-society/action-82-implementaudiovisual-media-services-directive.

European Parliament 1997. Directive 97/36/EC of the European Parliament and of the Council of 30 June 1997 amending Council Directive 89/552/EEC on the coordination of certain provisions laid down by law, regulation or administrative action in Member States concerning the pursuit of television broadcasting activities. http://eur-lex.europa.eu/LexUriServ/ LexUriServ.do?uri=CELEX:31997L0036:EN:HTML. European Parliament 2007. Directive 2007/65/EC of the European Parliament and of the Council of 11 December 2007 amending Council Directive 89/552/EEC on the coordination of certain provisions laid down by law, regulation or administrative action in Member States concerning the pursuit of television broadcasting activities. http://eur-lex.europa.eu/LexUriServ/LexUriServ. do?uri=OJ:L:2007:332:0027:01:EN:HTML.

European Parliament 2010. European Parliament resolution of 25 November 2010 on public service broadcasting in the digital era: the future of the dual system. http://www.europarl.europa.eu/sides/ getDoc.do?pubRef=-//EP//TEXT+TA+P7-TA-2010$0438+0+D O C+X M L+V 0 / / E N$.

Eurostat 2015. GDP per capita, consumption per capita and price level indices. http://ec.europa.eu/ eurostat/statistics-explained/index.php/GDP_per_ capita,_consumption_per_capita_and_price_level_ indices\#Relative_volumes_of_GDP_per_capita. Kanal 2 AS 2000-2014. Majandusaasta aruanne. https://www.krediidiinfo.ee/.

Riigikogu 1994. Ringhäälinguseadus.

https://www.riigiteataja.ee/akt/831359.

Riigikogu 1997a. Reklaamiseaduse rakendamisega seotud õigusaktide muutmise seadus.

https://www.riigiteataja.ee/ert/act.jsp?id=74425.

Riigikogu 1997b. Reklaamiseadus.

https://www.riigiteataja.ee/akt/73728.

Riigikogu 1999. Ringhäälinguseaduse muutmise seadus. https://www.riigiteataja.ee/ert/act.jsp?id $=77606$.

Riigikogu 2000. Ringhäälinguseaduse muutmise seadus. https://www.riigiteataja.ee/ert/act. jsp?id=71964\&replstring $=33$.

Riigikogu 2001. Ringhäälinguseaduse muutmise seadus. http://www.kul.ee/webeditor/files/

Broadcasting_Act.doc.

Riigikogu 2002. Ringhäälinguseaduse muutmise seadus. https://www.riigiteataja.ee/ert/act.jsp?id=162838. Riigikogu 2007. Estonian Public Broadcasting Act. https://www.riigiteataja.ee/en/eli/509012014002/ consolide.

Riigikogu 2010. Media Services Act.

https://www.riigiteataja.ee/en/eli/ee/509072014004/ consolide.

Riigikogu 2012. Elektroonilise side seaduse $§ 90$ täiendamise seadus. https://www.riigiteataja.ee/ akt/107112012001.

Technical Regulatory Authority 2015.

Meediateenuste load_nimekiri.

http://www.tja.ee/meediateenuste-load-2/.

The Maastrich Treaty. Treaty on European Union 1992. http://www.eurotreaties.com/maastrichtext.html.

The World Bank 2015. Data. Estonia.

http://data.worldbank.org/country/estonia.

TNS Emor 2014. Estonian Media Advertising Market. http://www.emor.ee/uudiste-arhiiv/.

TNS Emor 2015. TV-audience overview. May. http://www.emor.ee/teleauditooriumi-ulevaademaikuus-2015/.

Treaty establishing the European Economic Community 1957. http://eur-lex.europa.eu/en/treaties/ index.htm\#founding

TV3 AS 2000-2014. Majandusaasta aruanne. https://www.krediidiinfo.ee/.

All sources retrieved on 25 September 2015. 